\title{
Transient Macroamylasemia in a Severely Multiple-Handicapped Child Following the Development of Acute Bronchitis
}

\author{
Yoshihiko Sakurai \\ Department of Pediatrics, Matsubara Tokushukai Hospital, Matsubara, Japan \\ Email: ysakurai-th@umin.ac.jp
}

Received 5 August 2015; accepted 1 September 2015; published 4 September 2015

Copyright (C) 2015 by author and Scientific Research Publishing Inc.

This work is licensed under the Creative Commons Attribution International License (CC BY). http://creativecommons.org/licenses/by/4.0/

(c) (i) Open Access

\section{Abstract}

Macroamylasemia is a condition of elevated serum amylase levels in which normal serum amylase form a complex with high molecular weight proteins such as immunoglobulins. This is a case report on a patient with macroamylasemia following acute asthmatic bronchitis. A 5-year-old male with cerebral palsy and developmental retardation was admitted to our hospital because of high fever and severe cough. Treatment of the respiratory symptoms provided symptomatic improvement, but the serum amylase levels became suddenly elevated. Although acute pancreatitis associated with respiratory infection was initially suspected, a predominant salivary isoamylase, normal serum lipase level, low urine amylase level, and low amylase-creatinine clearance ratio (ACCR) $(0.58 \%)$ indicated macroamylasemia. The serum amylase level decreased, and the ACCR increased within normal range 2 weeks after discharge. Both of these indicators have been within normal range over the past year. Transient macroamylasemia can be misdiagnosed as acute pancreatitis, especially in a severely multiple-handicapped child who is unable to complain. The ACCR is useful in the diagnosis of macroamylasemia.

\section{Keywords}

Acute Respiratory Infections, Amylase-Creatinine Clearance Ratio (ACCR), Macroamylasemia, Multiple-Handicapped Child

\section{Introduction}

Macroamylasemia is a condition in which normal serum amylase form a complex with high molecular weight proteins such as immunoglobulin A and rarely immunoglobulin G [1]. In 1964, Wilding et al. firstly described 
the presence in circulating blood of an enzymatically active macromolecular amylase-immunoglobulin complex as a cause of persistent hyperamylasemia [2]. In 1967, Berk et al. referred to this condition as macroamylasemia [3]. Macroamylase undergoes a slower renal clearance rate due to its high molecular mass over a wide range (molecular weight, 150,000 - 2,000,000 Da) [4]. A decrease in the urinary excretion of amylase results in retention in blood and an elevation in the serum amylase levels. Macroamylasemia reportedly occurs in $2.5 \%$ of all hyperamylasemic patients, and in $1 \%$ of apparently healthy adults with normal amylase levels [1]. It has been associated with various diseases such as celiac disease, lymphoma, the human immunodeficiency virus infection, monoclonal gammopathy, rheumatoid arthritis, and ulcerative colitis. The exact prevalence of macroamylasemia in children remains unknown, and there have only been a few reports on pediatric cases with celiac disease [5], lymphoma in Wiskott-Aldrich syndrome [6], Crohn disease [7], and appendicitis [8]. In the present case, a severely multiple-handicapped boy had a significantly elevated plasma amylase level while in the hospital for acute asthmatic bronchitis.

\section{Case Presentation}

A 5-year-old male was admitted to our hospital with complaints of high fever and severe cough. He had hypoxic-ischemic encephalopathy in addition to severe perinatal asphyxia, epilepsy, developmental disorder, esophageal hiatal hernia, gastroesophageal reflux, and food allergy to eggs and peanuts. The patient had been managed at another hospital with eperisone, tizanidine, and chlordiazepoxide for intractable myotonia. An elemental diet had been administered through a nasogastric tube. His family history was unremarkable, and his past history showed frequent hospitalization because of recurrent lower respiratory tract infection.

One month before admission, he underwent gastrostomy successfully at another hospital for nutritional support, because nasogastric tube feeding did not fully protect against aspiration or ensure an adequate nutrition intake. Fervescence and cough developed 3 days before admission and persisted. A physical examination on admission showed marked emaciation (height, $100 \mathrm{~cm}$; body weight, $9.8 \mathrm{~kg}$ ) with a high temperature $\left(38.9^{\circ} \mathrm{C}\right)$ and tachypnea (respiratory rate, $52 / \mathrm{min}$ ). The saturation of peripheral oxygen with a pulse oximeter was $88 \%$. Chest auscultation revealed bilateral fine inspiratory crackles and end expiratory wheeze. Laboratory investigations demonstrated a white blood cell count of $4800 / \mu \mathrm{L}$ with normal differential. C-reactive protein (CRP) was markedly increased at $14.71 \mathrm{mg} / \mathrm{dL}$, and procalcitonin was $2.42 \mathrm{ng} / \mathrm{mL}$. No other significant abnormality was found in the blood biochemical tests, including the amylase level. Rapid diagnostic tests for the RS virus, adenovirus, and mycoplasma were all negative. Chest radiograph revealed an infiltrative shadow in the right hilar region and lower lung field. Although a low white blood cell count that is still within normal range may result from an overwhelming infection that exhausts white blood cells faster than they can be produced, hepatic dysfunction, renal dysfunction, and coagulopathy that are frequently observed in such a severe infection were not evident. Based on these findings, he was diagnosed with acute asthmatic bronchitis. Short-acting bronchodilators, inhaled corticosteroids, and intravenous antibiotics were commenced. He also received intravenous fluids to prevent dehydration. A congested nose developed and the creatine kinase levels increased probably due to hypertonia; these symptoms and aberrant values were transiently observed after admission. However, his respiratory status was gradually improved, and he became lively and active on hospital day 9. On hospital day 10, the CRP level was decreased to $0.14 \mathrm{mg} / \mathrm{dL}$ within normal range, but only a modest increase in amylase was observed (189 IU/L). Dysfunction of the liver and kidney was not evident. A change in facial expression was unclear when the parotid gland and submaxillary gland were palpated. No swelling of the glands was observed. On the assumption that the mild elevation of amylase was transient, he stayed out overnight at his home on a trial basis. He returned to the hospital without any incident on the following day (12). In anticipation of discharge, blood examination was conducted, which revealed an unexpected further elevation in amylase (443 IU/L). Abdominal tenderness was unclear. Suspecting acute pancreatitis associated with acute infection, abdominal ultrasound imaging was performed, but it could not depict the pancreas very clearly. Since oozing blood from the puncture site was persistent, clotting function tests were performed but revealed normal clotting ability except for a mild prolongation of prothrombin time (PT): PT (13.4 sec), activated partial thromboplastin time (APTT, $29.0 \mathrm{sec}$ ), fibrinogen $(332 \mathrm{mg} / \mathrm{dL}$ ), fibrin and fibrinogen degradation product (FDP, $<2.5 \mu \mathrm{g} / \mathrm{mL}$ ), and D-dimer $(<0.5$ $\mu \mathrm{g} / \mathrm{mL}$ ). Blood chemistry revealed that the serum lipase level was within normal range (16 U/L). Amylase isoenzyme analysis revealed that the pancreatic amylase was $6 \%$, while the salivary amylase was $94 \%$. Furthermore, urine amylase was below the lower limit of normal (73 IU/L), and the amylase-creatinine clearance 
ratio (ACCR) was calculated to be $0.58 \%$. Based on these findings, the patient was diagnosed with macroamylasemia, and he was discharged on hospital day 17 after observing the clinical course. Two weeks after discharge, the amylase level was decreased within normal range (59 IU/L), and the ACCR was increased to more than 1\% (1.12\%). The serum amylase level and ACCR have been within normal range over the past year.

\section{Discussion}

In the present case, the serum amylase levels were elevated during the convalescent phase of acute asthmatic bronchitis. Since tenderness and swelling of the salivary glands were not evident, mumps was likely negative and acute pancreatitis was suspected. Pancreatitis is a rare condition in children. The predominant causes for developing pancreatitis in children include trauma; congenital pancreaticobiliary malformations; drugs such as anticonvulsant valproate; toxins; viral infections; hereditary disorders; and metabolic disorders [9]. In the present case, acute pancreatitis associated with respiratory infection or drugs was initially suspected. However, on the basis of the laboratory findings, including the normal level of serum lipase, lower level of urine amylase, and reduced ACCR, macroamylasemia was diagnosed. Serum lipase is a useful backup test to confirm pancreatic insufficiency [10], while serum amylase is a sensitive marker. In macroamylasemia, amylase levels increase in blood and decrease in urine, resulting in the reduction of ACCR. It is well accepted that ACCR is very useful for diagnosing macroamylasemia [11] [12]. ACCR shows 1\% - 5\% in normal individuals. ACCR decrease to less than $1 \%$ in macroamylasemia, whereas significant elevation is observed in acute pancreatitis [13]. It was difficult to interpret physical findings in the current patient; however, a decrease in the ACCR aided in the differential diagnosis.

In the present case, as the amylase level elevated on hospital day 12 in the convalescent phase of acute respiratory infection, immunoglobulins exhibiting a cross reactivity with amylase might emerge with an increase in immunoglobulins against a pathogenic organism. This might cause macroamylasemia to develop.

To our knowledge, there have been few reports on acute respiratory infections-associated macroamylasemia.

\section{Conclusion}

Our case indicates the possible development of transient macroamylasemia in pediatric patients with acute respiratory infections. When encountering a patient with hyperamylasemia, the possibility of macroamylasemia should be considered in the differential diagnosis. In addition, the ACCR is helpful in differentiating between acute pancreatitis and macroamylasemia.

\section{References}

[1] Klonoff, D.C. (1980) Macroamylasemia and Other Immunoglobulin-Complexed Enzyme Disorders. Western Journal of Medicine, 133, 392-407.

[2] Wilding, P., Cooke, W. and Nicholson, G. (1964) Globulin-Bound Amylase: A Cause of Persistently Elevated Levels in Serum. Annals of Internal Medicine, 60, 1053-1059. http://dx.doi.org/10.7326/0003-4819-60-6-1053

[3] Berk, J.E., Kizu, H., Wilding, P. and Searcy, R.L. (1967) Macroamylasemia: A Newly Recognized Cause for Elevated Serum Amylase Activity. The New England Journal of Medicine, 277, 941-946. http://dx.doi.org/10.1056/NEJM196711022771801

[4] Levitt, M.D., Duane, W.C., and Cooperband, S.R. (1972) Study of Macroamylase Complexes. The Journal of Laboratory and Clinical Medicine, 80, 414-422.

[5] Barera, G., Bazzigaluppi, E., Viscardi, M., Renzetti, F., Bianchi, C., Chiumello, G. and Bosi, E. (2001) Macroamylasemia Attributable to Gluten-Related Amylase Autoantibodies: A Case Report. Pediatrics, 107, E93. http://dx.doi.org/10.1542/peds.107.6.e93

[6] Yoshida, K., Minegishi, Y., Okawa, H., Yata, J., Tokoi, S., Kitagawa, T. and Utagawa, T. (1997) Epstein-Barr virus-Associated Malignant Lymphoma with Macroamylasemia and Monoclonal Gammopathy in a Patient with WiskottAldrich Syndrome. Pediatric Hematology and Oncology, 14, 85-89. http://dx.doi.org/10.3109/08880019709030889

[7] Venkataraman, D., Howarth, L., Beattie, R.M. and Afzal, N.A. (2012) A Very High Amylase Can Be Benign in Paediatric Crohn's Disease. BMJ Case Reports, 2012. http://dx.doi.org/10.1136/bcr.02.2012.5917

[8] Ko, J. and Lee, D. (2009) Macroamylasemia in a 4-Year-Old Girl with Abdominal Pain. Korean Journal of Pediatrics, 52, 1283-1285. http://dx.doi.org/10.3345/kjp.2009.52.11.1283 
[9] Li, H., Qian, Z., Liu, Z., Liu, X., Han, X. and Kang, H. (2010) Risk Factors and Outcome of Acute Renal Failure in Patients with Severe Acute Pancreatitis. The Journal of Critical Care, 25, 225-229. http://dx.doi.org/10.1016/j.jcrc.2009.07.009

[10] Winslet, M., Hall, C., London, N.J. and Neoptolemos, J.P. (1992) Relation of Diagnostic Serum Amylase Levels to Aetiology and Severity of Acute Pancreatitis. Gut, 33, 982-986. http://dx.doi.org/10.1136/gut.33.7.982

[11] Levitt, M.D., Rapoport, M. and Cooperband, S.R. (1969) The Renal Clearance of Amylase in Renal Insufficiency, Acute Pancreatitis, and Macroamylasemia. Annals of Internal Medicine, 71, 919-925. http://dx.doi.org/10.7326/0003-4819-71-5-919

[12] Kazmierczak, S.C., Van Lente, F., McHugh, A.M. and Katzin, W.E. (1988) Macroamylasemia with a Markedly Increased Amylase Clearance Ratio in a Patient with Renal Cell Carcinoma. Clinical Chemistry, 34, 435-438.

[13] Murray, W.R. and Mackay, C. (1977) The Amylase Creatinine Clearance Ratio in Acute Pancreatitis. British Journal of Surgery, 64, 189-191. http://dx.doi.org/10.1002/bjs.1800640311 